\title{
Analisa Keseimbangan Energi PLTU Takalar (Punagaya) Unit 2 Berdasarkan Perubahan Beban
}

\author{
Makmur Saini $^{{ }^{*} \text {, Nur Hamzah }}{ }^{2}$, dan Devi Prasetyo Utomo ${ }^{3}$ \\ 1,2,3 Jurusan Teknik Mesin, Politeknik Negeri Ujung Pandang, Makassar 90245, Indonesia \\ *makmur_saini@poliupg.ac.id
}

\begin{abstract}
This study aims to calculate the efficiency and heat rate of the unit 2 PLTU Takalar (Punagaya) system with the energy balance calculation method, calculate the NPHR value of PLTU Takalar (Punagaya) unit 2 when the unit is operating, and also to determine the energy loss from the conversion energy results at PLTU Takalar (Punagaya) unit 2 when the unit operates. The PLTU's Net Plant Heat Rate (NPHR) value is a very important role as an indicator of the performance of a steam power plant. The real-time NPHR value calculation using the energy balance method can be used as an evaluation material to control the operation pattern of the generator in order to obtain optimal operation. The method used in this research is to collect direct and indirect data to calculate the energy balance and NPHR of PLTU Takalar (Punagaya) unit 2 during the reliability run period. The calculations carried out include the calculation of the energy balance in the boiler, the energy balance in the steam cycle, the balance of electrical energy, the efficiency of the PLTU and NPHR systems. Based on the results of calculations that have been carried out the efficiency and NPHR of PLTU Takalar (Punagaya) unit 2 is the best during the reliability run of $32.76 \%$ and $2801.93 \mathrm{kcal} / \mathrm{kWh}$ at full load conditions with an energy loss value of 220.60 MW. The performance of PLTU Takalar (Punagaya) unit 2 during the reliability run is very good where the unit operates continuously and the NPHR value when full load fulfills the contract warranty and the maximum operating target.
\end{abstract}

Keywords: Steam Power Plant; NPHR; Heat Rate; Efficiency.

\begin{abstract}
Abstrak: Penelitian ini bertujuan untuk menghitung efisiensi dan heat rate sistem PLTU Takalar (Punagaya) unit 2 dengan metode perhitungan keseimbangan energi (energy balance), menghitung nilai NPHR PLTU Takalar (Punagaya) unit 2 saat unit beroperasi, dan juga untuk mengetahui kerugian energi dari hasil konversi energi pada PLTU Takalar (Punagaya) unit 2 saat unit beroperasi. Nilai Net Plant Heat Rate (NPHR) PLTU memegang peranan yang sangat sebagai indikator kinerja suatu pembangkit listrik tenaga uap. Perhitungan nilai NPHR secara realtime dengan metode keseimbangan energi dapat digunakan sebagai bahan evaluasi untuk mengendalikan pola pengoperasian pembangkit agar diperolah pengoperasian yang optimal. Metode yang digunakan dalam penelitian ini adalah dengan melakukan pengambilan data langsung dan tidak langsung untuk menghitung keseimbangan energi dan NPHR PLTU Takalar (Punagaya) unit 2 pada masa reliability run. Perhitungan yang dilakukan meliputi perhitungan keseimbangan energi pada boiler, keseimbangan energi pada siklus uap, keseimbangan energi listrik, efisiensi sistem PLTU dan NPHR. Berdasarkan hasil perhitungan yang telah dilakukan efisiensi dan NPHR PLTU Takalar (Punagaya) unit 2 terbaik selama masa reliability run sebesar $32,76 \%$ dan 2801,93 kcal/kWh pada kondisi beban full load dengan nilai kerugian energy sebesar 220,60 MW. Performa PLTU Takalar (Punagaya) unit 2 pada masa reliability run sangat baik dimana unit beroperasi secara kontinyu dan nilai NPHR ketika full load memenuhi garansi kontrak dan target maksimum operasi.
\end{abstract}

Kata kunci : PLTU, NPHR, Heat Rate; Efisiensi.

\section{PENDAhULUAN}

PT PLN (Persero) mencatatkan penjualan listrik sebesar 17,57 Terra Watt Hour (TWh) di sepanjang Januari 2016, meningkat 7,54 persen dibandingkan penjualan listrik di periode yang sama tahun lalu pada angka 16,34 TWh. Kebutuhan listrik Nasional rata-rata tumbuh sekitar 8 - $9 \%$ per tahun. Sehingga Pemerintah Indonesia setiap tahun membutuhkan tambahan pembangkit tenaga listrik untuk memenuhi beban beban konsumen baik saat beban dasar ataupun beban puncak.

PLTU Takalar (Punagaya) merupakan salah satu proyek PT PLN (Persero) yang ada di Indonesia, tepatnya berada di Provinsi Sulawesi Selatan. PT PLN (Persero) UPP KITRING SULSEL 
selaku owner dibantu oleh PT PLN Enjiniring sebagai supervisi konstruksi dan PT PLN (Persero) PUSERTIF selaku supervisi komisioning saling bekerja sama untuk menyelesaikan salah satu proyek milik PLN ini. PLTU Takalar (Punagaya) ini mulai beroperasi secara komersil pada 28 November 2017 untuk unit 1 dan 28 Februari 2018 untuk unit 2.

Faktor efisiensi merupakan hal yang sangat penting dan selalu menjadi pembahasan utama di dalam setiap pembangkit listrik. Berdasarkan uji regresi linier yang telah dilakukan [1], nilai heat rate memiliki pengaruh yang besar atau sangat signifikan terhadap kinerja suatu PLTU. Heat rate merupakan kebalikan dari efisiensi maka heat rate yang lebih rendah berarti semakin baik efisiensi suatu pembangkit listrik tenaga uap [2]. Nilai Nett Plant Heat Rate dan efisiensi saat ini memegang peranan penting, selain sebagai salah satu parameter penilaian yang sering disebut dengan Performance Base Regulatory. Nilai heat rate sangat penting untuk menghitung biaya operasi dan laba untuk sebuah pembangkit.

Pada studi observasional PLTU di PT. Indocement Tunggal Prakarsa, Tbk P-12 TarjunKalimantan Selatan [3], diperoleh Nilai tertinggi NPHR adalah sebesar 3580,77 $\mathrm{kcal} / \mathrm{kWh}$ pada saat beban 29,86 MW, Sedangkan nilai terkecil NPHR adalah $2594,57 \mathrm{kcal} / \mathrm{kWh}$ pada saat beban 47,8 MW. Efisiensi PLTU tertinggi adalah sebesar 33,54 \% pada saat beban 47,8 MW, efisiensi PLTU terkecil adalah 26,27 \% pada saat beban 29,86 MW. Pengaruh beban generator terhadap efisiensi adalah sebesar 56,06 \%, maka dari itu PLTU akan semakin efisien dan optimal jika dioperasikan pada beban generator tinggi.

Pada studi PLTU Tanjung Jati B Unit 3 [4], diperoleh nilai turbine heat rate terendah yaitu $7981,97 \mathrm{~kJ} / \mathrm{kWh}$ dengan efisiensi turbin $45,1 \%$, dan nilai turbine heat rate tertinggi yaitu 8043,122 $\mathrm{kJ} / \mathrm{kWh}$ dengan efisiensi turbin $44,75 \%$.

Pada studi di PT. Indonesia Power Unit Jasa Pembangkitan jawa barat pada operasional Unit 2 Palabuhan Ratu [5], diperoleh nilai tertinggi GPHR dan NPHR senilai 2714 dan 2872 saat pemakaian batubara kalori 4206 pada beban 240 MW dan nilai terendah GPHR dan NPHR senilai 2401 dan 2523 saat memakai batubara dengan kalori 4431 pada beban $320 \mathrm{MW}$, nilai efisiensi thermal tertinggi senilai $35,8 \%$ saat pemakaian batubara dengan kalori 4431 pada beban 320 MW dan effisiensi terendah senilai 31,68\% saat pemakaian batubara kalori 4206 pada beban $240 \mathrm{MW}$.

Pada studi di pembangkit listrik tenaga uap di Nii Tanasa kecamatan Soropia kabupaten Konawe dengan kapasitas 2 x10 Mega watt [6], diperoleh nilai NPHR (Net Plant heat race) pada bulan januari 4.986,87 kkal/kWh., sedangkan pada bulan juni nilai rata-rata NPHR Nilai rata-rata adalah 5.070,10 kkal/kWh. "berdasarkan batas NPHR diusulkan oleh Generator listrik Negara (PLN) masih dalam batas standar operasi.

Studi pada PLTU X [7], diperoleh bahwa dari perhitungan yang dilakukan diketahui bahwa heat rate sangat erat kaitannya dengan efisiensi. Hasil perhitungan efisiensi yang diperoleh sebesar $51,5 \%$ terlalu besar dimana biasanya hanya sekitar $35 \%$.

Studi simulasi cycle tempo pada PLTU Paiton Unit 9 [8], diperoleh kondisi optimal yaitu NPHR terendah 2452,047 $\mathrm{kCal} / \mathrm{kWh}$ dan efisiensi sistem tertinggi yaitu 35,236\%, yang paling merugikan adalah NPHR terbesar $2513,818 \mathrm{kCal} / \mathrm{kWh}$ dan efisiensi sistem terendah yaitu $34,37 \%$.

Pada studi penggunaan spesifikasi batubara yang berbeda [9], dibandingkan pengujian komissioning di peroleh efisiensi boiler (HHV basis) pada pengujian aktual 100\% LRC mengalami penurunan sebesar 3,25\% dan pada pengujian dengan komposisi $50 \%$ LRC dan $50 \%$ MRC mengalami penurunan sebesar $2,91 \%$, dibandingkan hasil komisioning pada beban maksimum turbine heat rate pada 2 (dua) pengujian aktual 100\% LRC masing-masing sebesar 1.994,67 $\mathrm{kcal} / \mathrm{kWh}$ dan 1.981,55 kcal/kWh sedangkan pada pengujian dengan komposisi $50 \%$ LRC dan $50 \%$ MRC Turbine Heat Rate adalah $1.977,52 \mathrm{kcal} / \mathrm{kWh}$. Nilai tersebut lebih rendah 4,47\% dan 3,78\% untuk pengujian $100 \% \mathrm{LRC}$ dan lebih rendah $3,45 \%$ untuk pengujian $50 \%$ LRC dan $50 \%$ MRC. 
Berdasarkan hasil-hasil pada studi di atas maka dilakukan penelitian dengan judul "Analisa Keseimbangan Energi PLTU Takalar (Punagaya) Unit 2 Berdasarkan Perubahan Beban" untuk menentukan nilai efisiensi dan nilai NPHR dengan perhitungan keseimbangan energi dari proses konversi energi yang terkandung dalam batubara hingga menjadi energi listrik pada generator sesuai dengan perubahan beban. Melalui metode perhitungan heat rate pembangkit yang melibatkan parameter data dari sisi boiler, turbin dan generator, proses identifikasi letak penurunan efisiensi pembangkit akan lebih mudah, apakah dari sisi boiler, turbin atau generator.

\section{METODE PENELITIAN}

Penelitian dilakukan di PLTU Takalar (Punagaya) unit 2, adapun metode penelitian yang digunakan adalah studi pustaka dan studi lapangan, yaitu:

\section{A. Studi Pustaka}

Metode ini dilakukan dengan membaca buku-buku sebagai referensi yang berupa description and calculation book dan manual book yang ada di kantor proyek PLN UPP KITRING SULSEL PLTU Takalar (Punagaya), buku tentang pengoperasian pembangkit dari PLN Corporate University dan buku-buku lain yang mempunyai keterkaitan dengan sistem pembangkit listrik tenaga uap, serta mencari sumber informasi lainnya sebagai dasar teori.

\section{B. Studi Lapangan}

Metode ini dilakukan dengan pengamatan dan pengumpulan data untuk memperoleh parameterparameter yang digunakan dalam perhitungan energy balance PLTU Takalar (Punagaya) unit 2. Pengambilan data dilakukan secara langsung dan tidak langsung. Pengambilan data secara langsung dilakukan dengan mencatat langsung data pengukuran oleh alat ukur yang ada dilokal yang sudah terintegrasi dengan sistem DCS (Distributed Control System) PLTU Takalar (Punagaya) unit 2 yang berada pada komputer master di ruangan EWS. Pengambilan data secara tidak langsung dilakukan dengan bantuan table sifat uap dan aplikasi steam table. Data yang diambil adalah Enthalpy Specific (h) dan Enthropy Specific (s). Aplikasi yang digunakan untuk mendapatkan data tersebut adalah Microsoft Excel dengan tambahan Add-In Water97_v13.xla - Excel Add-In for Properties of Water and Steam in SI-Units Version 1.3 - 10 February 2002, Copyright 2000-2002 by Bernhard Spang, Hamburg, Germany.

\section{HASIL DAN PEMBAHASAN}

\section{A. Hasil}

Tabel 1. Keseimbangan Energi PLTU Takalar (Punagaya) unit 2

\begin{tabular}{|c|c|c|c|c|c|c|c|c|c|c|c|}
\hline \multirow[t]{2}{*}{ Waktu } & $\begin{array}{l}\text { Energi } \\
\text { Input }\end{array}$ & $\begin{array}{l}\text { Energi } \\
\text { Boiler }\end{array}$ & $\begin{array}{l}\text { Energi } \\
\text { Siklus } \\
\text { Uap }\end{array}$ & $\begin{array}{c}\text { Generator } \\
\text { Gross } \\
\text { Output } \\
\text { Power }\end{array}$ & $\begin{array}{c}\text { Generator } \\
\text { Nett } \\
\text { Output } \\
\text { Power }\end{array}$ & $\begin{array}{l}\text { Energi } \\
\text { Losses } \\
\text { Boiler }\end{array}$ & $\begin{array}{c}\text { Energi } \\
\text { Losses } \\
\text { Siklus } \\
\text { Uap }\end{array}$ & $\begin{array}{c}\text { Aux } \\
\text { Power }\end{array}$ & $\begin{array}{c}\text { Eff } \\
\text { Boiler }\end{array}$ & $\begin{array}{c}\text { Eff } \\
\text { Siklus } \\
\text { Uap }\end{array}$ & $\begin{array}{l}\text { Eff } \\
\text { Sistem } \\
\text { PLTU }\end{array}$ \\
\hline & MW & MW & MW & MW & MW & MW & MW & MW & $\%$ & $\%$ & $\%$ \\
\hline 10-Jan-18 & 221.01 & 158.69 & 160.10 & 66.63 & 58.64 & 62.33 & 93.35 & 8.00 & 71.81 & 41.72 & 26.54 \\
\hline 11-Jan-18 & 220.25 & 157.39 & 159.60 & 67.04 & 59.02 & 62.87 & 92.44 & 8.02 & 71.46 & 42.10 & 26.80 \\
\hline 12-Jan-18 & 199.36 & 151.41 & 153.65 & 64.92 & 56.86 & 47.95 & 88.61 & 8.06 & 75.97 & 42.37 & 28.53 \\
\hline 13-Jan-18 & 193.08 & 143.87 & 146.52 & 60.95 & 52.79 & 49.21 & 85.45 & 8.17 & 74.62 & 41.67 & 27.39 \\
\hline 14-Jan-18 & 209.62 & 154.90 & 157.21 & 62.56 & 54.35 & 54.72 & 94.53 & 8.21 & 73.90 & 39.91 & 25.93 \\
\hline 15-Jan-18 & 185.31 & 151.50 & 153.42 & 58.04 & 50.15 & 33.81 & 95.27 & 7.89 & 81.78 & 37.90 & 27.06 \\
\hline 16-Jan-18 & 189.71 & 160.05 & 161.86 & 61.93 & 53.95 & 29.67 & 99.81 & 7.99 & 84.41 & 38.34 & 28.47 \\
\hline 17-Jan-18 & 202.40 & 151.76 & 154.03 & 58.87 & 50.96 & 50.64 & 95.05 & 7.91 & 75.07 & 38.29 & 25.21 \\
\hline 18-Jan-18 & 174.79 & 141.25 & 145.06 & 52.79 & 45.11 & 33.53 & 92.16 & 7.68 & 81.36 & 36.34 & 25.79 \\
\hline 19-Jan-19 & 148.42 & 125.59 & 128.71 & 44.98 & 37.77 & 22.83 & 83.63 & 7.22 & 84.62 & 35.02 & 25.44 \\
\hline 20-Jan-18 & 150.74 & 126.25 & 128.52 & 45.17 & 38.15 & 24.49 & 83.25 & 7.03 & 83.77 & 35.23 & 25.31 \\
\hline
\end{tabular}


SINERGI NO. 2, TAHUN 18, OKTOBER 2020260

\begin{tabular}{|l|r|r|r|r|r|r|r|r|r|r|r|}
\hline 21-Jan-18 & 221.97 & 159.08 & 160.62 & 63.74 & 55.82 & 62.89 & 96.76 & 7.92 & 72.56 & 38.79 & 24.55 \\
\hline 22-Jan-18 & 329.91 & 254.96 & 257.63 & 111.76 & 101.32 & 74.95 & 145.65 & 10.44 & 77.38 & 43.47 & 30.76 \\
\hline 23-Jan-18 & 351.56 & 262.65 & 264.81 & 112.80 & 102.36 & 88.92 & 151.80 & 10.44 & 74.84 & 42.68 & 29.17 \\
\hline 24-Jan-18 & 362.61 & 257.33 & 259.62 & 111.80 & 101.34 & 105.28 & 147.60 & 10.46 & 71.43 & 43.15 & 28.13 \\
\hline 25-Jan-18 & 339.90 & 253.62 & 255.75 & 110.26 & 99.96 & 86.28 & 145.28 & 10.30 & 75.22 & 43.19 & 29.64 \\
\hline 26-Jan-18 & 218.17 & 178.59 & 180.82 & 71.21 & 62.90 & 39.58 & 109.48 & 8.31 & 82.58 & 39.38 & 28.96 \\
\hline 27-Jan-18 & 210.64 & 179.82 & 182.13 & 70.62 & 62.57 & 30.82 & 111.39 & 8.05 & 85.38 & 38.85 & 29.71 \\
\hline 28-Jan-18 & 214.39 & 180.63 & 183.01 & 70.31 & 62.22 & 33.75 & 112.58 & 8.09 & 84.37 & 38.49 & 29.07 \\
\hline 29-Jan-18 & 235.44 & 182.46 & 184.21 & 70.61 & 62.45 & 52.99 & 113.48 & 8.15 & 77.63 & 38.40 & 26.57 \\
\hline 30-Jan-18 & 222.82 & 178.83 & 181.16 & 71.13 & 62.98 & 43.99 & 109.90 & 8.15 & 80.33 & 39.36 & 28.28 \\
\hline 31-Jan-18 & 223.18 & 175.40 & 177.63 & 70.21 & 62.07 & 47.78 & 107.29 & 8.14 & 78.62 & 39.60 & 27.82 \\
\hline 1-Feb-18 & 228.06 & 177.43 & 179.68 & 70.14 & 61.96 & 50.63 & 109.41 & 8.18 & 77.86 & 39.11 & 27.19 \\
\hline 2-Feb-18 & 233.84 & 178.88 & 181.21 & 70.46 & 62.22 & 54.96 & 110.62 & 8.24 & 76.71 & 38.97 & 26.70 \\
\hline 3-Feb-18 & 216.21 & 180.17 & 181.68 & 72.92 & 64.72 & 36.04 & 108.63 & 8.20 & 83.32 & 40.23 & 29.93 \\
\hline 4-Feb-18 & 220.89 & 185.73 & 187.80 & 74.00 & 65.81 & 35.16 & 113.67 & 8.19 & 84.13 & 39.48 & 29.81 \\
\hline 5-Feb-18 & 230.35 & 190.40 & 191.89 & 74.94 & 66.78 & 39.95 & 116.81 & 8.16 & 82.74 & 39.13 & 29.02 \\
\hline 6-Feb-18 & 193.59 & 157.35 & 159.32 & 60.68 & 52.96 & 36.24 & 98.53 & 7.71 & 81.04 & 38.02 & 27.11 \\
\hline 7-Feb-18 & 177.66 & 141.52 & 143.48 & 53.40 & 45.99 & 36.14 & 89.98 & 7.41 & 79.72 & 37.27 & 25.91 \\
\hline 8-Feb-18 & 180.07 & 139.99 & 141.71 & 51.39 & 43.96 & 40.08 & 90.22 & 7.43 & 78.07 & 36.33 & 24.52 \\
\hline 9-Feb-18 & 227.34 & 170.39 & 171.54 & 65.56 & 57.63 & 56.95 & 105.87 & 7.93 & 75.20 & 37.88 & 25.04 \\
\hline
\end{tabular}

Tabel 2. Efisiensi Sistem PLTU dan NPHR

\begin{tabular}{|c|c|c|c|c|}
\hline \multirow{2}{*}{ Waktu } & Energi Input & $\begin{array}{l}\text { Generator Nett } \\
\text { Output Power }\end{array}$ & $\begin{array}{l}\text { Efisiensi Sistem } \\
\text { PLTU }\end{array}$ & NPHR \\
\hline & MW & MW & $\%$ & $\mathrm{kcal} / \mathrm{kWh}$ \\
\hline 10-Jan-18 & 221.01 & 58.64 & 26.54 & 3243.57 \\
\hline 11-Jan-18 & 220.25 & 59.02 & 26.80 & 3213.41 \\
\hline 12-Jan-18 & 199.36 & 56.86 & 28.53 & 3018.68 \\
\hline 13-Jan-18 & 193.08 & 52.79 & 27.39 & 3156.78 \\
\hline 14-Jan-18 & 209.62 & 54.35 & 25.93 & 3321.69 \\
\hline 15-Jan-18 & 185.31 & 50.15 & 27.06 & 3180.56 \\
\hline 16-Jan-18 & 189.71 & 53.95 & 28.47 & 3030.23 \\
\hline 17-Jan-18 & 202.40 & 50.96 & 25.21 & 3421.98 \\
\hline 18-Jan-18 & 174.79 & 45.11 & 25.79 & 3340.45 \\
\hline 19-Jan-19 & 148.42 & 37.77 & 25.44 & 3388.07 \\
\hline 20-Jan-18 & 150.74 & 38.15 & 25.31 & 3400.88 \\
\hline 21-Jan-18 & 221.97 & 55.82 & 24.55 & 3558.92 \\
\hline 22-Jan-18 & 329.91 & 101.32 & 30.76 & 2801.93 \\
\hline 23-Jan-18 & 351.56 & 102.36 & 29.17 & 2955.62 \\
\hline 24-Jan-18 & 362.61 & 101.34 & 28.13 & 3079.83 \\
\hline $25-\operatorname{Jan}-18$ & 339.90 & 99.96 & 29.64 & 2926.56 \\
\hline 26-Jan-18 & 218.17 & 62.90 & 28.96 & 2981.54 \\
\hline 27-Jan-18 & 210.64 & 62.57 & 29.71 & 2896.96 \\
\hline 28-Jan-18 & 214.39 & 62.22 & 29.07 & 2967.90 \\
\hline 29-Jan-18 & 235.44 & 62.45 & 26.57 & 3246.68 \\
\hline 30-Jan-18 & 222.82 & 62.98 & 28.28 & 3045.07 \\
\hline 31-Jan-18 & 223.18 & 62.07 & 27.82 & 3094.53 \\
\hline 01-Feb-18 & 228.06 & 61.96 & 27.19 & 3168.90 \\
\hline 02-Feb-18 & 233.84 & 62.22 & 26.70 & 3234.99 \\
\hline 03-Feb-18 & 216.21 & 64.72 & 29.93 & 2875.79 \\
\hline 04-Feb-18 & 220.89 & 65.81 & 29.81 & 2889.48 \\
\hline 05-Feb-18 & 230.35 & 66.78 & 29.02 & 2969.91 \\
\hline 06-Feb-18 & 193.59 & 52.96 & 27.11 & 3192.43 \\
\hline 07-Feb-18 & 177.66 & 45.99 & 25.91 & 3337.18 \\
\hline
\end{tabular}


261 Makmur Saini, Nur Hamzah, Devi Prasetyo Utomo. Analisa Keseimbangan Energi PLTU Takalar (Punagaya) Unit 2 Berdasarkan Perubahan Beban

\begin{tabular}{|r|r|r|r|r|}
\hline 08-Feb-18 & 180.07 & 43.96 & 24.52 & 3540.07 \\
\hline 09-Feb-18 & 227.34 & 57.63 & 25.04 & 3453.96 \\
\hline
\end{tabular}

\section{B. Pembahasan}

Berdasarkan perhitungan yang telah dilakukan maka dapat digambarkan beberapa grafik sebagaimana berikut:

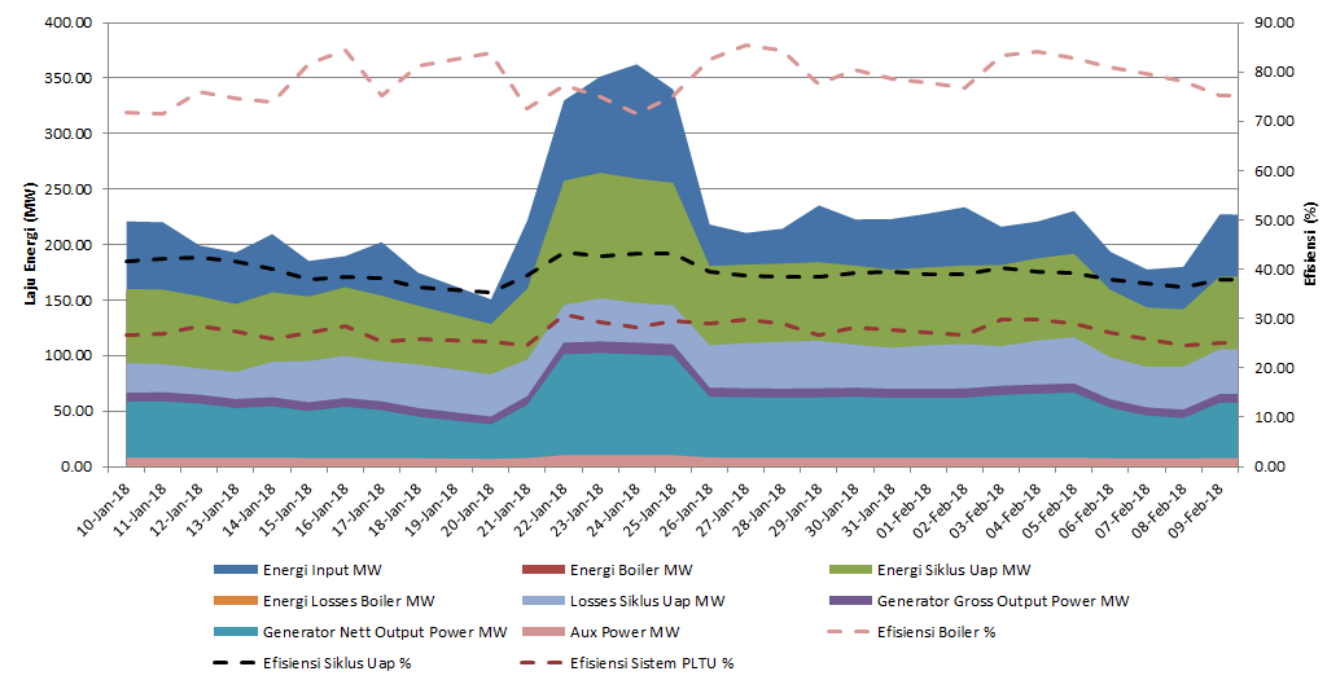

Gambar 1. Keseimbangan energi PLTU Takalar (Punagaya) unit 2

Gambar 1 menunjukkan keseimbangan energi PLTU Takalr (Punagaya) unit 2 berdasarkan perubahan beban selama beroperasi masa reliability run. Grafik tersebut menampilkan perubahan laju energi dan nilai kehilangan energi pada proses konversi energi input batubara menjadi energi listrik yang di suplai ke sistem kelistrikan Sulawesi Selatan. Energi listrik terbesar yang disuplai ke sistem adalah 104,12 MW pada 23 Januari 2018 dengan nilai efisiensi unit PLTU sebesar 28,38\%. Efisiensi PLTU terbesar adalah 32,77\% yang terjadi pada 22 Januari 2018 dengan kondisi generator menyuplai beban netto ke sistem sebesar 102,5 MW.

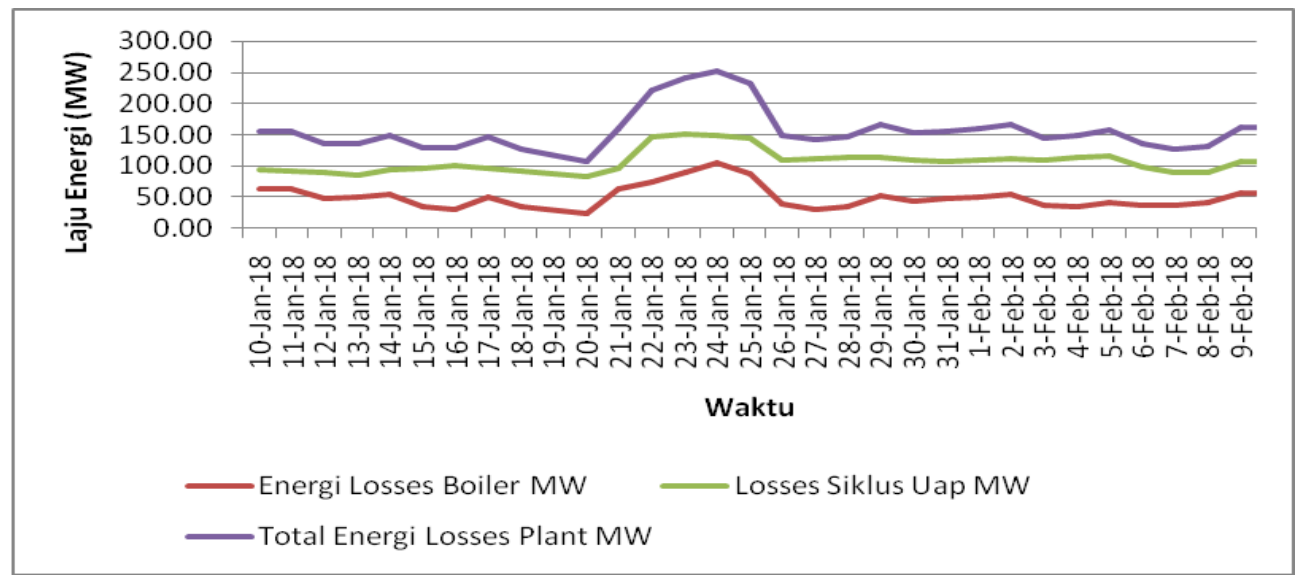

Gambar 2. Kehilangan energi PLTU 
Gambar 2 menunjukkan grafik kehilangan energi PLTU Takalar (Punagaya) unit 2 selama masa reliability run. Kehilangan energi terbesar PLTU Takalar (Punagaya) unit 2 adalah sebesar 298,353 MW yang terjadi pada 24 Januari 2018 dengan rincian kehilangan energi panas boiler sebesar 147,668 MW dan kehilangan energi siklus uap sebesar 150,684 MW. Kehilangan energi panas yang terjadi pada boiler pada umumnya diakibatkan karena proses perpindahan panas yang tidak maksimum yang disebabkan oleh jelaga-jelaga pada pipa-pipa boiler dan banyaknya kandungan debu pada batubara sehingga panas justru terbuang bersama dengan gas buang (flue gas) dan debu batubara (bottom ash dan fly ash). Faktor lain yang menyebabkan kehilangan panas adalah keluarnya panas bersamaan dengan air blowdown pada boiler. Sementara itu kehilangan energi pada siklus uap diakibatkan oleh venting-venting dan drain pada sistem turbin.

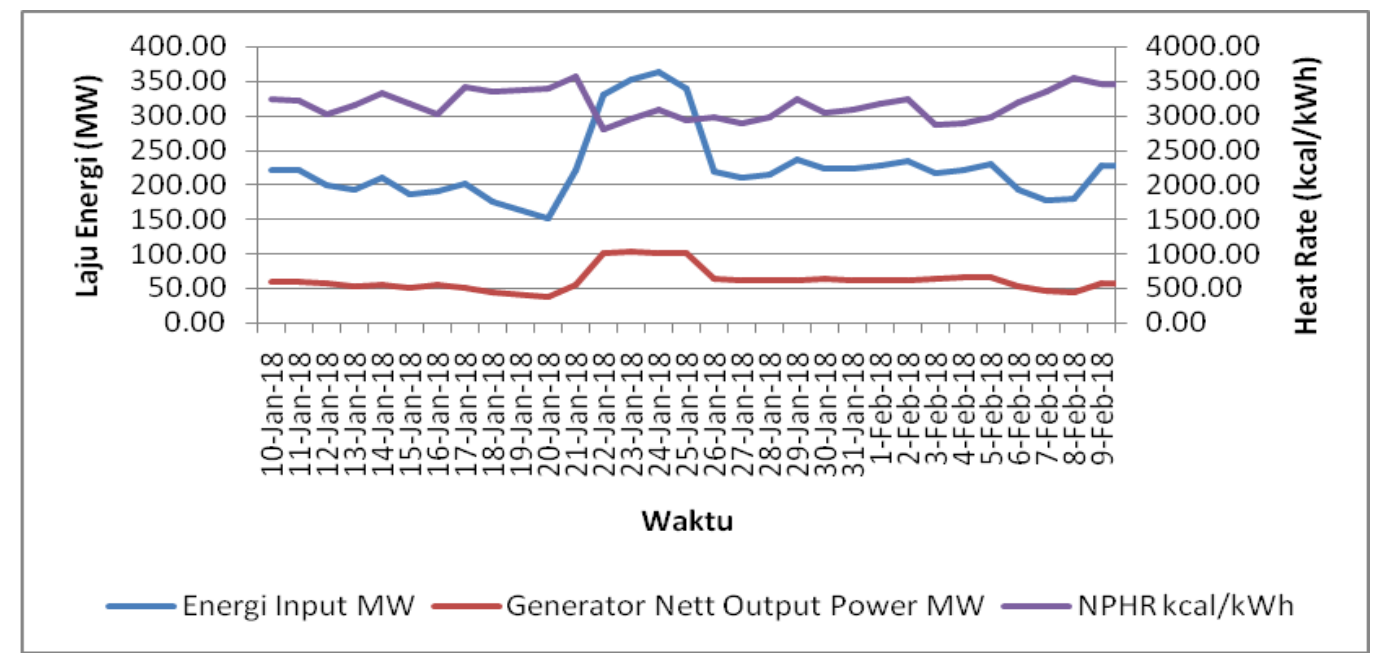

Gambar 3. Perbandingan NPHR, energi input dan energi listrik

Berdasarkan gambar 3, nilai NPHR PLTU Takalar (Punagaya) unit 2 terbaik adalah 2801,93 $\mathrm{kcal} / \mathrm{kWh}$ dengan beban pembangkit netto 101,32 MW. Sementara itu NPHR PLTU terburuk adalah $3558,92 \mathrm{kcal} / \mathrm{kWh}$ dengan beban pembangkit netto 55,82 MW. Semakin tinggi beban operasi pembangkit, maka nilai NPHR cenderung semakin rendah karena pemanfaatan energi input batubara dapat digunakan secara maksimal oleh komponen-komponen PLTU untuk beroperasi pada kondisi maksimumnya

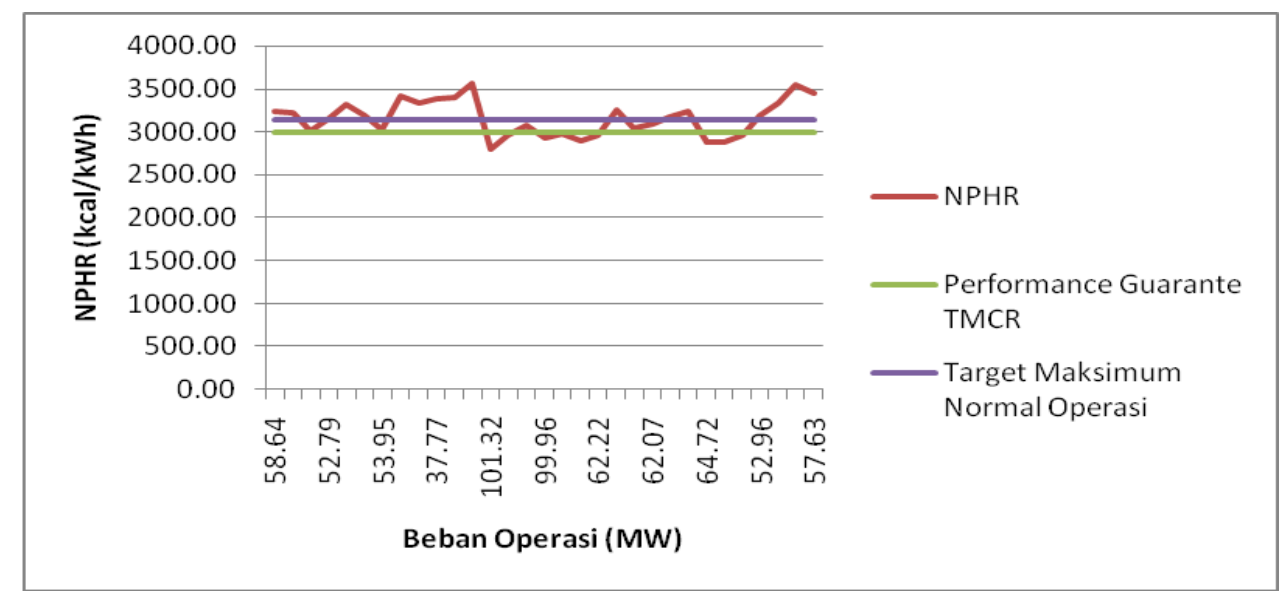

Gambar 4. Kinerja NPHR PLTU Takalar (Punagaya) 
Berdasarkan gambar 4, NPHR PLTU Takalar (Punagaya) unit 2 selama operasi ditunjukkan oleh garis warna merah, dimana nilai NPHR rendah ketika beban PLTU maksimum. Garis warna hijau merupakan nilai batasan maksimum NPHR garansi yang disebutkan didalam kontrak kerjasama PLN dengan kontraktor saat kondisi TMCR (turbin beroperasi dengan kondisi maksimum dimana semua blowdown di tutup). Nampak bahwa ketika unit beroperasi pada kondisi full load, NPHR PLTU berada dibawah atau sejajar dengan garis warna hijau, yang mengartikan bahwa kondisi unit bagus dan memenuhi kontrak. Sementara itu garis warna ungu merupakan target maksimum normal operasi harian PLTU. Berdasarkan grafik tersebut namak bahwa ketika pembangkit beroperasi pada beban rendah (dibawah 60\%) nilai NPHR nya cenderung tinggi.

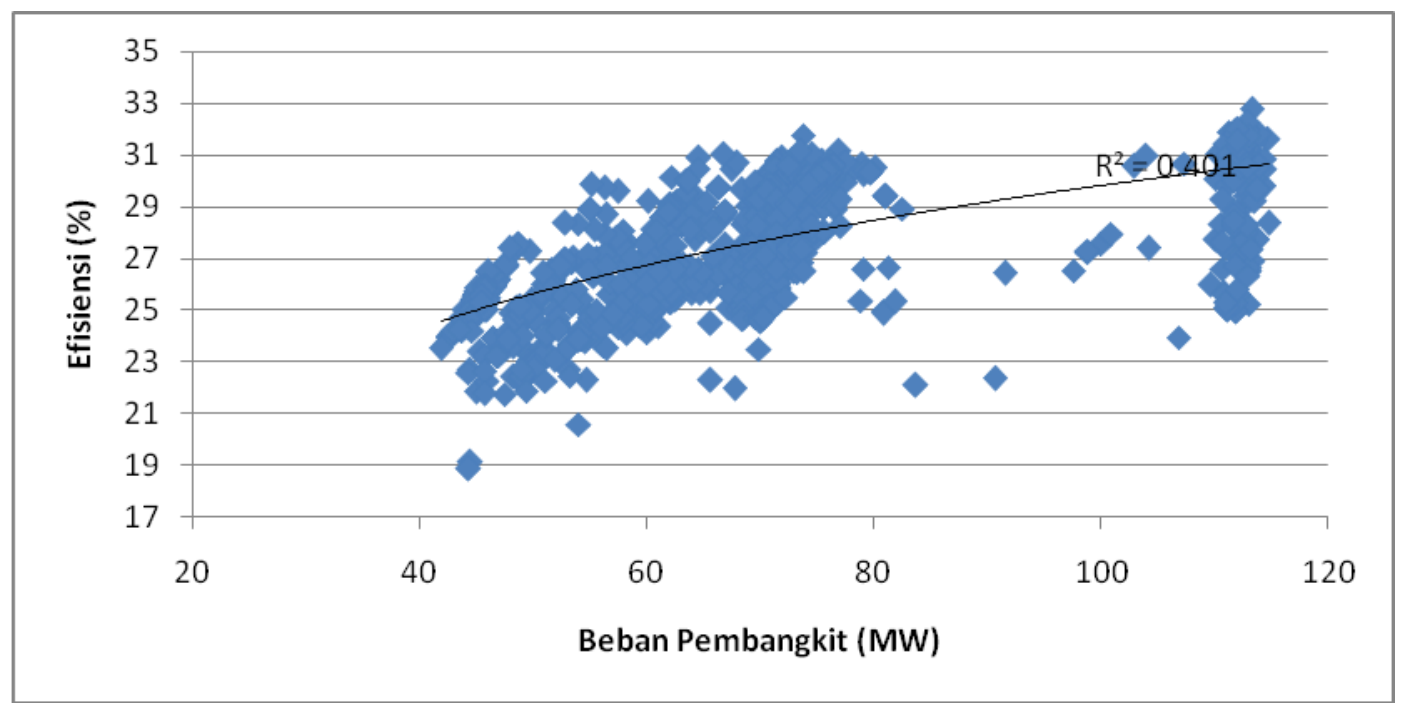

Gambar 5. Hubungan efisiensi unit PLTU terhadap perubahan beban

Berdasarkan gambar 5 tersebut terlihat bahwa hubungan efisiensi unit PLTU dengan perubahan beban sebanding, dimana semakin tinggi beban operasi PLTU maka semakin baik pula efisiensi unit PLTU tersebut dan semakin rendah beban operasi PLTU maka semakin rendah pula nilai efisiensi unitnya.

\section{KESIMPULAN}

Berdasarkan hasil dan pembahasan yang telah dituangkan dalam bentuk tabel dan grafik, maka dapat disimpulankan beberapa hal, yaitu:

a. Efisiensi sistem PLTU Takalar (Punagaya) terbaik ketika masa reliability run adalah $32,76 \%$ dengan beban operasi pembangkit 113,27 MW.

b. Nilai NPHR PLTU Takalar (Punagaya) terbaik ketika masa reliability run adalah 2801,93 $\mathrm{kcal} / \mathrm{kWh}$ dengan beban pembangkit netto 101,32 MW.

c. Kehilangan energi sistem PLTU Takalar (Punagaya) terbesar ketika masa reliability run adalah 298,353 MW.

d. Performa PLTU Takalar (Punagaya) unit 2 ketika masa reliability run sangat baik dimana unit beroperasi kontinyu tanpa adanya kondisi lepas sinkron dan nilai NPHR ketika unit beroperasi pada kondisi full load memenuhi garansi kontrak dan target maksimum normal operasi. 


\section{DAFTAR PUSTAKA}

[1] Kurniawan, Hanzen Yauri, Hardi Gunawan, dan Benny Maluegha. "Kajian Efisiensi Termal Dari Boiler Di Pembangkit Listrik Tenaga Uap Amurang Unit 1." Jurnal Online Poros Teknik Mesin Unsrat 4.2 (2015)

[2] Prasetiyo, Budhi. "Heat rate pembangkit listrik tenaga uap Paiton baru (Unit 9) berdasarkan performance test tiap bulan dengan beban 100\%." Eksergi 12.2 (2016).

[3] Rizca, Muhammad Miftah Noor, Qomariyatus Sholehah, dan Sigit Siswanto. "Analisis beban generator terhadap nilai heat rate dan efisiensi PLTU (Studi observasional di PT. Indocement Tunggal Prakarsa, Tbk P-12 Tarjun-Kalimantan Selatan)." Scientific Journal of Mechanical Engineering Kinematika 3.2 (2018): 73-84.

[4] Mustofa, Bachrudin Azis. "Analisa heat rate pada turbin uap berdasarkan performance test PLTU Tanjung Jati B Unit 3." Eksergi 10.3 (2016).

[5] Syahputera, Muhammad Iqbal, Dianta Mustofa Kamal, dan Arifia Ekayuliana. "Analisis pengaruh nilai kalori batubara terhadap konsumsi bahan bakar dan biaya produksi listrik." Seminar Nasional Teknik Mesin 2018. 2019.

[6] Kadir, Kadir, et al. "Analisis sistem heat race net plant (NPHR) di Nii Tanasa pada pembangkit tenaga uap dengan kapasitas 2 x 10 MW." Dinamika: Jurnal Ilmiah Teknik Mesin 11.2 (2020): 4649.

[7] Sudarmaji, Wahyu. "Studi dan Analisis Heat Rate Pembangkit Listrik Tenaga Uap (PLTU) Batubara." (2019). Jurusan Teknik Elektro, Universitas Islam Indonesia Jl Kaliurang KM 14.5 Yogyakarta, Indonesia

[8] Ramadhanti, Narumi Dwi, dan Ary Bachtiar Krishna Putra. "Simulasi Cycle Tempo Pengaruh Kondisi Operasi HPH Off Service terhadap Performa PLTU Paiton Unit 9." Jurnal Teknik ITS 8.2 (2020): B63-B68.

[9] Aziz, Amiral, dan Andi Rinaldi Hasan. "Evaluasi Hate Rate dan Efisiensi suatu PLTU dengan menggunakan Batubara yang Berbeda dari Spesifikasi Design." Jurnal Energi dan Lingkungan (Enerlink) 11.1 (2015). 